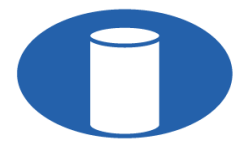

IBRACON Structures and Materials Journal

Revista IBRACON de Estruturas e Materiais

IBRACON

ISSN 1983-4195

ismj.org

ORIGINAL ARTICLE

\title{
Proposition of a simplified analytical design procedure for lattice girder slabs with shuttering in cold-formed steel lipped channel section
}

\section{Proposição de procedimento analítico simplificado para dimensionamento de lajes treliçadas com forma em perfil de aço formado a frio do tipo $U$ enrijecido}

Lucas Fadini Favarato ${ }^{\mathrm{a}, \mathrm{b}}$ (D)

André Vasconcelos Soares Gomes ${ }^{\mathrm{a}}$ (i)

Daniel Carvalho de Moura Candido ${ }^{\mathrm{a}}$ (D)

Adenilcia Fernanda Grobério Calenzani ${ }^{\mathrm{a}}$

Juliana da Cruz Vianna Pires ${ }^{\mathrm{a}}$ (D)

Johann Andrade Ferrareto ${ }^{\mathrm{b}}$

${ }^{a}$ Universidade Federal do Espírito Santo - UFES, Programa de Pós-graduação em Engenharia Civil, Vitória, ES, Brasil

${ }^{\mathrm{b}}$ ArcelorMittal Tubarão, Serra, ES, Brasil

Received 01 September 2019

Accepted 13 February 2020

\begin{abstract}
This paper presents an analytical procedure to determine the resistance of a new composite ribbed lattice slab system, composed by a lipped channel cold-formed steel (CFS) profile in minor bending fastened to a lattice girder by plastic connectors, as well as light filling elements and additional rebar. Motivated by the lack of standardized procedures for such system, this paper combines slab design prescriptions to create a computational tool that estimates load capacity and required propping during construction, serving as a basis for a design catalogue. Finally, a strong limitation of unpropped construction due to the low performance of the cold-formed profile under minor axis bending was observed, being the system able to reach spans up to $1.5 \mathrm{~m}$ between props in general.
\end{abstract}

Keywords: lattice girder slab, cold-formed steel shuttering, design procedure, composite slab, span and live-load.

Resumo: Este artigo apresenta um procedimento analítico para determinação da resistência de um novo sistema de lajes mistas nervuradas treliçadas, composto por um perfil de aço formado a frio (PFF) do tipo $U$ enrijecido fletido em torno do eixo de menor inércia acoplado a uma treliça eletrossoldada através de conectores plásticos, além de blocos de enchimento e armaduras adicionais. Em decorrência da falta de procedimentos normatizados para esse tipo de sistema, este trabalho combina métodos de dimensionamento de lajes em uma ferramenta computacional capaz de estimar as sobrecargas máximas e escoramento requerido na etapa de construção, base para a tabela de vãos e cargas. Por fim, observou-se forte limitação à construção não escorada pela baixa rigidez do perfil de aço, sendo o sistema capaz de atingir vãos entre escoras de até $1.5 \mathrm{~m}$, em média.

Palavras-chave: laje treliçada, forma de aço formado a frio, procedimento para dimensionamento, laje mista, tabela de vãos e cargas.

How to cite: L. F. Favarato, A. V. S. Gomes, D. C. M. Candido, A. F. G. Calenzani, J. C. V. Pires, and J. A. Ferrareto, "Proposition of a simplified analytical design procedure for lattice girder slabs with shuttering in cold-formed steel lipped channel section," Rev. IBRACON Estrut. Mater., vol. 13, no. 5, e13504, 2020, https://doi.org/10.1590/S1983-41952020000500004

Corresponding author: Lucas Fadini Favarato. E-mail: lucasffavarato@gmail.com, lucas.favarato@arcelormittal.com.br

Financial support: ArcelorMittal Tubarão, Federal University of Espirito Santo, CAPES, CNPq and FAPES.

Conflict of interest: Nothing to declare. 


\section{INTRODUCTION}

Since the beginning of the XIX century, structural engineering has undergone considerable changes in the development of structural materials and design methodologies. Initially presented as a combination of concrete or steel elements working independently, the first composite slab systems combining these materials were developed in the United States of America in 1930. Further studies resulted in the development of the steel deck slabs used in modern buildings [1], [2].

Steel-concrete composite systems present several benefits such as architectural flexibility, simplified construction procedures and diminished material waste. When compared to structures built exclusively of steel, composite structures may reduce the use of such material, as well as increase global structural stiffness. Alternatively, in comparison with reinforced concrete $(\mathrm{RC})$ structures, implementation of steel-concrete composite elements can result in improvements in constructional precision, reduction of weight and estimated time of construction, as well as considerable reduction of propping and shuttering [2]-[4]. As such, a steady increase in the use of structures of this nature, such as composite slabs, is observed. Although steel-concrete composite behavior may increase mechanical efficiency, there are specific design cases in which the composite behavior is not accounted for [1], [2].

In this context, a new composite slab system, called Trelifácil $\AA$, was developed as an alternative for the traditional lattice girder precast concrete slabs. The system is composed by a CFS lipped channel section subjected to minor axis bending, fastened to a lattice girder by uniformly distributed plastic spacers, as shown in Figure 1. The system also uses filling material, such as Expanded Polystyrene, additional rebar if needed, and concrete. Some of the advantages of using Trelifácil@, as stated by the manufacturer are; ease of assembly, $80 \%$ weight reduction of each rib, increased dimensional precision during construction and improvements on safety and ergonomic conditions during assembly. Furthermore, since concrete casting occurs in a single stage, as opposed to the interaction of concrete with distinct curing ages observed in the traditional lattice girder slabs, less deformation and increased material homogeneity are expected during serviceability of Trelifácil ${ }^{\circledR}$ slabs [5].

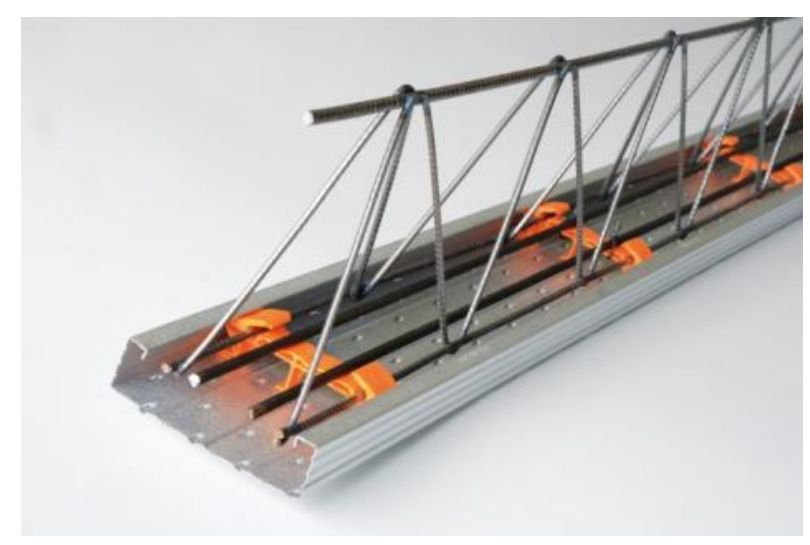

Figure 1. Single rib system - Trelifácil ${ }^{\circledR}[5]$.

In the structural arrangement, each rib behaves as a simply supported beam, subjected to bending about the minor axis of inertia of the CFS profile, with no negative rebar needed at the edges. The distance between ribs, occupied by filling material, depends on the size and type of said material, e.g., ceramic or polystyrene blocks, in accordance to the Brazilian national standard ABNT NBR 14859-2 [6]. Parameters that influence final resistance are: compressive strength of the concrete, additional rebar, thickness of concrete layer and lattice girder geometry. Due to the similarity between the aforementioned system and unidirectional ribbed slabs, Trelifácil ${ }^{\circledR}$ may be considered as a set of juxtaposed concrete " $T$ " beams. Thus, for design considerations, a portion of the concrete, adjacent to each rib, contributes significantly to the resistance of compressive forces acting on a given rib cross section.

As a consequence of insufficient research aimed at the mechanical behavior of Trelifácil ${ }^{\circledR}$, the present study provides a simplified analytical design procedure for this system, based on a computational tool created as a combination of the Brazilian design standards ABNT NBR 14762 [7], ABNT NBR 8800 [8], ABNT NBR 6118 [9] and ABNT NBR 14859-2 [6]. 


\section{RECENT ADVANCES IN COMPOSITE SLAB RESEARCH}

A rational design of flooring systems produces high impact to the overall weight of steel or composite steel-concrete buildings and it becomes more significant with the increased demand for higher column spacing. Moreover, the reduction in floor depth due to composite construction may offer many benefits regarding to costs reduction and structural performance enhancement [10]. Despite the previously mentioned demand for studies on the mechanical behavior of the Trelifácil ${ }^{\circledR}$ system, there is a considerable amount of academic studies concerning similar types of steel-concrete composite structures.

Experimentally, Andrade et al. [11] assessed the shear resistance and ultimate material slip strength of a composite wide-rib steel deck system as a function of web corrugations and indentations with different slopes, as well as additional shear transfer devices implemented on a new proposal of composite slab system. Vianna et al. [12] performed a numerical optimization of a cold-formed steel profile, subsequentially used for the proposal of a steel deck composite slab configuration. The authors then determined flexural and material slip strengths of the new system by means of 4-point flexure tests and push-out tests, respectively. Performance comparisons were drawn in relation to similar slab systems, and noticeable financial and workability advantages are observed.

Jeong [13] conducted several non-linear partial steel-concrete interaction experimental analyses on slab prototypes with different degrees of steel-concrete interaction and shear-span ratios. The results were compared with data extracted from push-out tests and statistical analyses to investigate the reliability of the model to predict partial composite behavior. The same experimental tests were carried out by Vianna et al. [14], [15] to assess the resistance of T-Perfobond shear connectors used in composite beams or columns, focusing on shear transfer capacity, ductility and collapse modes. Design guidelines for this connector were proposed and the devices proved to be an efficient and economical solution for shear transfer in steel concrete composite elements.

Holomek and Bajer [16] investigated the shear behavior of CFS corrugated sheets with embossments, by means of full-scale four-point bending and vacuum tests, as well as shear tests on a reduced scale. The numerical models were calibrated with test results in order to assess the load bearing capacity of the slab. Hsu et al. [17] performed 12 full-scale tests on a beam-floor system consisting of a concrete slab supported by a corrugated CFS deck, CFS joists and continuous cold-formed shear connectors. The moment carrying capacity, end slip strength and vertical displacement are compared with a non-composite section. Results indicate an increase in mechanical resistance of 14-38\% and no shear or compression buckling of the composite section was observed.

Still within the field of experimental research, many authors have explored the structural efficiency of steel-concrete composite beams and slabs related to the material properties of concrete, with variation in material composition and/or inclusion of chemical additives. Such studies include the investigations performed by Alenezi et al. [18], Hossain et al. [19], Lasheen et al. [20] and Waldmann et al. [21].

A number of numerically oriented studies concerning the topic at hand are also observed in academic literature. Majdi et al. [22] proposed a non-linear tridimensional finite element analysis (FEA) via ANSYS to simulate a four-point bending test of a composite floor. The models considered multi-linear material behavior and large-displacement theory, and numerical results present acceptable agreement with experimental tests. Despite the finite element (FE) model yielding conservative results, these were suitable for posterior parametric analyses.

Florides and Cashell [23] developed and validated a FE model via ABAQUS and VULCAN, to investigate failure behavior of composite one-directional and two-directional reinforced floors at ambient and elevated temperatures. The model included time-dependent material properties attributed to temperature change, as well as geometric nonlinearities. Experimental tests served as a basis to validate the model. Suizi et al. [24] performed cyclic load tests on frame-supported ribbed-grid composite slabs (FSRGCS). The authors used the IDARC program to elaborate a mathematical model using the hysteretic law of Park's degradation. ANSYS was then used to simulate load capacity and seismic performance of the slab system considering elastoplastic material. The results were consistent with the experiments.

Hossain et al. [25] elaborated a non-linear Finite Element model to study the behavior of steel deck composite slabs using Engineered Cementitious Composite (ECC). The numerical model was validated with experimental tests and a parametric study was conducted to assess the influence of various parameters. Numerical and experimental results were in agreement and suggest a superior ductile behavior of ECC slabs in relation to self-consolidating concrete (SCC) counterparts. Zhou et al. [26] studied the flexural capacity of a composite floor with lightweight cold-formed channel joists and oriented strand boards. A FE model was developed and validated by experimental test results, followed by a parametric study to determine how screw and joist spacing, as well as plate thickness, affect flexural strength. Local buckling was observed to be the critical failure mode of the joists and a tendency of lateral-torsional buckling was also observed. The study culminated in a simplified model to predict the bending capacity of these slabs. 


\subsection{Recent advances in design procedures for composite slabs}

The scope of this topic is to present recent researches that proposed optimizations of standardized design procedures. Kyvelou et al. [27] provided practical design rules for composite CFS beams and wood-based floorboards, suitable for future incorporation in European standards. They demonstrated the proposed method by comparing results from twelve experimental tests with numerical analyses available in the literature, focusing on moment capacity and flexural stiffness.

Chien and Ritchie [28] summarized the main recommendations for the design of composite structures based on in-situ experience. The authors presented the main characteristics that contributed to the successful implementation of the systems. The study focused on conventional beam-girder, composite steel trusses and stud-girders as systems used for composite floors. These items were discussed and additional comments regarding deck-slab interaction and slab reinforcing requirements were made. Johnson and Shepherd [29] analyzed composite slabs with trapezoidal steel sheeting and longitudinal reinforcements, found to significantly contribute to shear resistance. The research proposed a design procedure that accounts for these elements, based on experimental data. Furthermore, the authors analyzed the contribution of reinforcements to the strength of partial interaction between materials. It is concluded that shear strength at material interface is not affected by additional reinforcements.

Limazie and Chen [30] analyzed elastic and plastic moment capacity of composite slim floor beams, and suggested a design procedure for these elements, validated by comparisons with existing research data. A predictive model was elaborated, considering material nonlinearity and composite behavior at material interface. The relations between moment and curvature, as well as moment and displacement, were also provided. Ranzi and Ostinelli [31] conducted an experimental study on post-tensioned composite slabs to assess ultimate resistance with relation to slab thickness, number of prestressing strands, span length and continuity of profile sheeting. A mathematical model was supplied for calculation of bending capacity, and the theoretical approach was compared with experimental data, demonstrating acceptable agreement.

In closure, $\mathrm{Li}$ et al. [32] presented an energy-based method to assess the structural response of steel beam-concrete slabs subjected to side column removal scenarios. A resistance-displacement curve was proposed and parametric studies were carried out to investigate the effect of various parameters. The proposed method was compared to numerical results and a difference of less than $15 \%$ is noted.

\section{PROPOSITION OF ANALYTICAL DESIGN PROCEDURE}

The simplified analytical design procedure proposed for Trelifácil ${ }^{\circledR}$ slabs is detailed in this topic. Whereas no previous researches are found in the literature for this exact floor system, Favarato et al. [33] suggested an alternative to assess the resistance of Trelifácil ${ }^{\circledR}$ for unpropped construction. Based on numerical buckling analyses, the author evaluates the maximum allowed unpropped span as well as maximum live load capacity. Nevertheless, on account of the high slenderness and low stiffness of the steel cross section, the unpropped spans can reach up to $1.40 \mathrm{~m}$ depending on section geometry [33]. Here, a computational tool is developed to estimate the number of props and maximum force applied on propping devices.

The general cross-section disposition of Trelifácil ${ }^{\circledR}$ slabs is shown in Figure 2a, and the cold-formed lipped channel section is detailed in Figure 2b. Different configurations are possible depending on concrete compressive strength, additional reinforcement, concrete layer thickness, lattice girder specification, density and dimensions of filling materials and yield strength of steel. This last parameter is taken as $280 \mathrm{MPa}$ in this research.

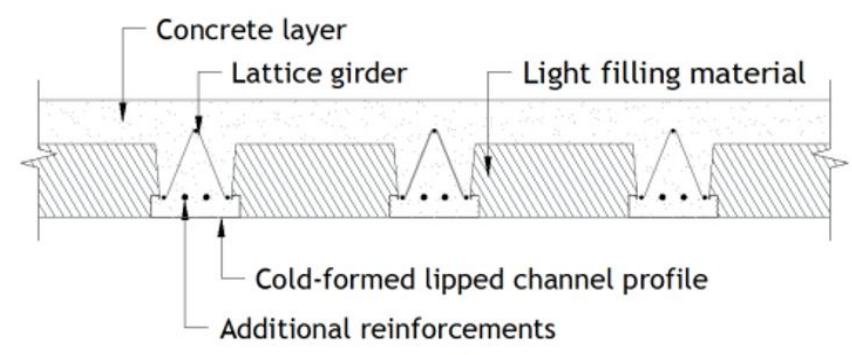

(a)

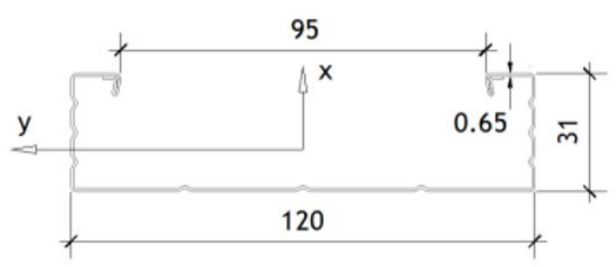

(b)

Figure 2. (a) General cross section of Trelifácil ${ }^{\circledR}$ slabs (extracted from Favarato et al. [33]); (b) cold-formed lipped channel cross section in $\mathrm{mm}$ (adapted from Favarato et al. [33]). 
Initially, the bending moment and shear resistance of concrete elements are determined considering ultimate limit state design recommendations. Additionally, the serviceability limit state of excessive deflection is also verified, accounting for the influence of creep and crack width of the concrete. Based on the span length $L$ and using the appropriate load combination, one can define the live load bearing capacity, in $\mathrm{kg} / \mathrm{m}^{2}$, that causes the predominant limit state [33].

Sequentially, the CFS shuttering is analyzed considering the ultimate limit states for combined bending, shear and web crippling. The serviceability limit state of excessive deflection is verified as well. The latter allows the calculation of the number of props and maximum force in each propping device. As a conservative approach, steel-concrete interaction during serviceability is not accounted for, hence, each steel and concrete system is designed separately. This arises from the absence of experimental data concerning the behavior of the system.

\subsection{Main assumptions}

The assumptions about the mechanical behavior of Trelifácil ${ }^{\circledR}$, that serve as basis for the proposition of a simplified design procedure are listed as follows.

a) The bending moment acts in a single direction, and the slab is simply supported by beams on opposite edges.

b) Before concrete curing, the cold-formed lipped channel steel section resists to all the dead loads (steel shuttering, concrete, lattice girder and filling material), in addition to a construction live load of $1 \mathrm{kN} / \mathrm{m}^{2}$.

c) Any possible additional resistance provided by the coupling of the lattice girder to the CFS profile is neglected. Thus, stiffness and resistance to combined bending and shear during construction, are estimated considering minor axis bending of the lipped channel profile exclusively.

d) Each concrete rib is assumed to behave as a simply supported T-shaped beam, and dimensions depend on filling element and steel profile geometry [33], in accordance with Figure 3. Equation 1 presents the dimensions shown in Figure 3 , in mm, in which $b_{b}$ is the width and $h_{b}$ the height of inert elements.

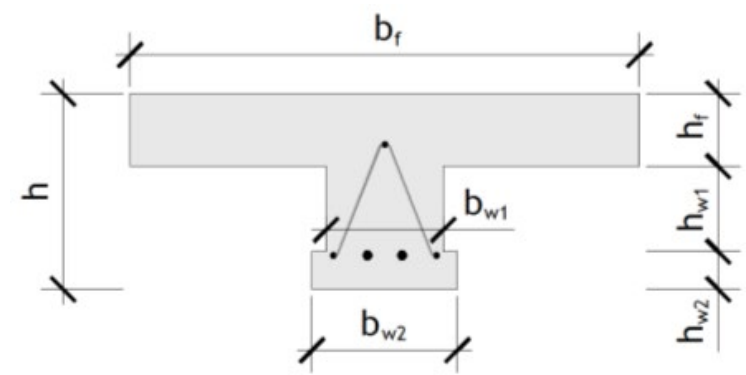

Figure 3. T-shaped concrete beam cross section (extracted from Favarato et al. [33]).

$$
\begin{aligned}
& b_{f}=b_{b}+95 \\
& h=h_{b}+h_{f} \\
& h_{f}=h_{c} \\
& b_{w 1}=95 \\
& b_{w 2}=120 \\
& h_{w 1}=h_{b}-31 \\
& h_{w 2}=31
\end{aligned}
$$

e) Conservatively, any lateral bracing provided to the CFS profile by the inert elements is neglected. Hence, the limit states related to lateral-torsional buckling must be verified. Nevertheless, linear elastic numerical analyses have shown that filling material may reduce the incidence of lateral-torsional buckling [34].

f) The contribution of the cold-formed steel profile to the resistance of the final slab is neglected. As such, after concrete curing, only concrete contributes to the final resistance. The design is also performed in the third domain of deformations of reinforced concrete sections [9], in order to guarantee ductile structural behavior. 
g) The filling elements are standardized by ABNT NBR 14859-2 [6]. Furthermore, block width $\left(b_{b}\right)$ should be no longer than $555 \mathrm{~mm}$ so that each T-shaped element can be designed using beam theory, without accounting for flange bending [9].

h) As a result of assumption g, the serviceability limit-state of crack width must be verified.

i) For medium spans, additional positive reinforcements may be provided to increase the resistance of the T-shaped beams. For longer spans, this inclusion may be done to reduce vertical displacement.

j) The lattice girders provide the shear resistance of the T-shaped concrete beams after curing. Whereas ABNT NBR 6118 [9] suggests a simplified criterion for slabs to assess the shear capacity, the full criterion for lattice girder beams is used.

k) Increases in yield strength of steel as result of cold forming are neglected.

1) The concrete must be produced with class 0 gravel to guarantee acceptable material homogeneity.

$\mathrm{m}$ ) Since this slab system is intended for construction in residential areas, class II of environmental aggressiveness was chosen. As such, in accordance with ABNT NBR 6118 [9], minimum rebar cover is taken as $25 \mathrm{~mm}$ and maximum crack width as $0.30 \mathrm{~mm}$.

n) When the maximum span of the cold-formed steel element is inferior to that of the concrete beam, the maximum length of the former, governs prop spacing.

o) The uniformly distributed propping must be placed under the steel shuttering in such a way that vertical and lateral displacements are constrained.

p) The propping elements are assumed to be rigid, behaving as hinge or roller supports for vertical loads.

q) The shuttering is designed as a continuous beam during construction stage and bending moment redistribution due to support displacements is not accounted for.

r) CFS profile limit-states govern structural safety during construction phase.

s) Before concrete curing, ponding is considered for steel shuttering design.

\subsection{Design before concrete curing}

Before concrete curing, the cold-formed steel shuttering must be verified as a continuous beam (Figure 4) and four limit-states are considered. Initially, the resistance to combined positive bending moment and shear force must be determined in the critical span. If propping is necessary, the limit state associated with combined negative bending moment and shear force must be considered as well, adjacent to intermediate supports. Subsequentially, support reactions must be small enough to avoid web crippling. Maximum deflection must also be verified.

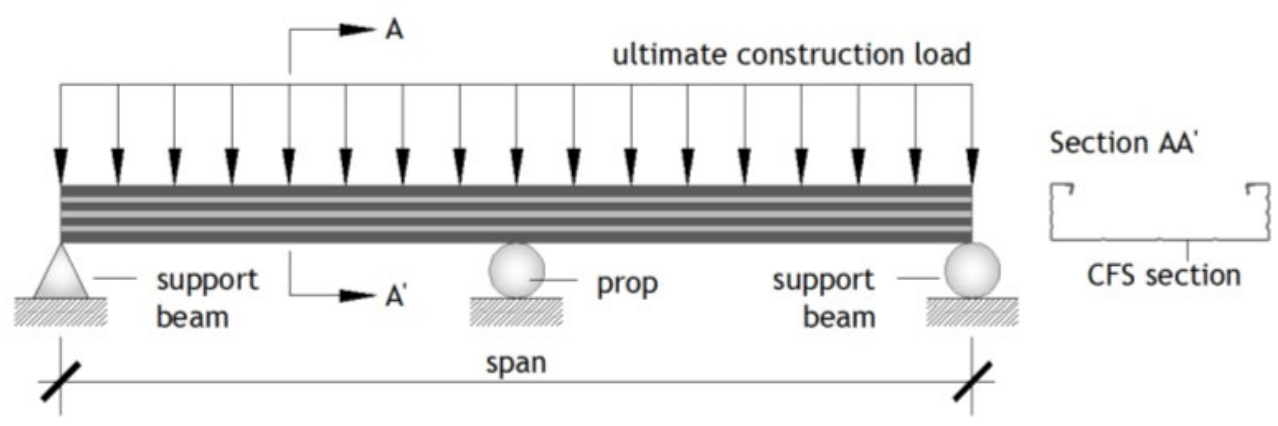

Figure 4. Structural arrangement of the steel shuttering (source: authors).

\subsubsection{Resistance to combined bending and shear}

The Direct Strength Method (DSM), prescribed in ABNT NBR 14762 [7], was chosen to assess the design resistance of cold-formed members, due to its simplicity since it considers the analysis of the gross cross section [7], [35]-[37]. The final resistance of elements under flexure depends on the occurrence of three limit-states related to global, distortional and local buckling. Global buckling parameters are determined with Equations 2 and 3: 
$\lambda_{0}=\sqrt{\frac{W f_{y}}{M_{e}}}$

$$
M_{k, R e}=\left\{\begin{array}{c}
W f_{y} \quad \lambda_{0} \leq 0.6 \\
1.11\left(1-0.278 \lambda_{0}^{2}\right) W f_{y} \quad 0.6<\lambda_{0} \leq 1.336 \\
\frac{W f_{y}}{\lambda_{0}^{2}} \quad \lambda_{0}>1.336
\end{array}\right.
$$

where $\lambda_{0}$ is the reduced slenderness attributed to global buckling; $f_{y}$ is the steel yield strength; $W$ is the elastic modulus about the minor axis of inertia; $M_{e}$ is the elastic critical moment of lateral-torsional buckling; and $M_{k, R e}$ is the characteristic value of resistant global bending moment. Local buckling parameters can be obtained by Equations 4 and 5:

$$
\lambda_{l}=\sqrt{\frac{M_{k, R e}}{M_{l}}}
$$

$M_{k, R l}=\left\{\begin{array}{c}M_{k, R e} \quad \lambda_{l} \leq 0.776 \\ \frac{M_{k, R e}}{\lambda_{l}^{0.8}}\left(1-\frac{0.15}{\lambda_{l}^{0.8}}\right) \quad \lambda_{l}>0.776\end{array}\right.$

where $\lambda_{l}$ is the reduced slenderness associated to local buckling; $M_{l}$ is the elastic critical moment of local buckling; and $M_{k, R l}$ is the characteristic value of resistant bending moment related to local buckling. Distortional buckling verification is performed according to Equation 6 and 7:

$$
\lambda_{\text {dist }}=\sqrt{\frac{W f_{y}}{M_{\text {dist }}}}
$$

$M_{k, \text { Rdist }}=\left\{\begin{array}{c}W f_{y} \quad \lambda_{\text {dist }} \leq 0.673 \\ \frac{W f_{y}}{\lambda_{\text {dist }}}\left(1-\frac{0.22}{\lambda_{\text {dist }}}\right) \quad \lambda_{\text {dist }}>0.673\end{array}\right.$

where $\lambda_{\text {dist }}$ is the reduced slenderness related to distortional buckling; $M_{\text {dist }}$ is the elastic critical moment of distortional buckling; and $M_{k, \text { Rdist }}$ is the characteristic value of resistant bending moment of distortional buckling. Finally, the design resistance for bending moment $\left(M_{R d}\right)$ is calculated using the smallest value obtained from Equations 3,5 and 7, as shown by Equation 8 .

$$
M_{R d} \leq \frac{1}{1.10}\left\{\begin{array}{c}
M_{k, R e} \\
M_{k, R l} \\
M_{k, R d i s t}
\end{array}\right.
$$

The design resistance to shear force $\left(V_{R d}\right)$ is calculated considering the limit-state of web buckling due to shear stress [7]. The procedure outlined in Equations 9 and 10 must be applied to all flat portions of the web $\left(h_{w}\right)$. It's important to state that, since the CFS profile is in minor bending, the flanges behave as webs and the web behaves as a single bottom flange. 
$\lambda_{w}=\frac{h_{w}}{t_{w}}$

$$
V_{R d} \leq\left\{\begin{array}{c}
\frac{0.6 h_{w} t_{w} f_{y}}{1.10} \quad \lambda_{w} \leq 1.08 \sqrt{\frac{E_{s} k_{v}}{f_{y}}} \\
\frac{0.65 t_{w}{ }^{2} \sqrt{k_{v} f_{y} E_{s}}}{1.10} \quad 1.08 \sqrt{\frac{E_{s} k_{v}}{f_{y}}}<\lambda_{w} \leq 1.40 \sqrt{\frac{E_{s} k_{v}}{f_{y}}} \\
\frac{0.905 E_{s} k_{v} t_{w}{ }^{3}}{1.10 h_{w}} \quad \lambda_{w}>1.40 \sqrt{\frac{E_{s} k_{v}}{f_{y}}}
\end{array}\right.
$$

where $t_{s}$ is web thickness; $E_{s}$ is Young's modulus $(200 \mathrm{GPa})$; and $k_{v}$ is the shear buckling coefficient, taken as 5 since no web stiffener has been considered. Following calculation of resistant bending moment and shear force, the combined resistance is verified according to Equation 11, where $M_{s d}$ and $V_{s d}$ are the design values for bending moment and shear force, respectively.

$$
\left(\frac{M_{s d}}{M_{R d}}\right)^{2}+\left(\frac{V_{s d}}{V_{R d}}\right)^{2} \leq 1
$$

\subsubsection{Evaluation of critical buckling bending moments}

The assessment of flexural resistance via DSM depends on the critical load related to global buckling, in a first moment, according to Equation 2. For lipped channel sections bent about the centroidal y-axis (perpendicular to the axis of symmetry, Figure 2b), $M_{e}$ is calculated according to Equation 12 [7], [36], [37].

$$
M_{e}=\frac{C_{s} N_{e x}}{C_{m}}\left[j+C_{s} \sqrt{j^{2}+r_{0}^{2}\left(\frac{N_{e z}}{N_{e x}}\right)}\right]
$$

It is important to state that $C_{s}$ accounts for the bending moment orientation, taken as - 1 for lips under compression and 1 for web under tension. The $C_{m}$ parameter accounts for the bending moment distribution in the element and is calculated in consonance with Equation 13.

$$
C_{m}=0,6-0,4 \frac{M_{1}}{M_{2}}
$$

where $M_{2}$ is the largest bending moment on the edges of the analyzed element; Alternatively, $M_{1}$ is the smallest one; in addition, $M_{1} / M_{2}>0$ for reverse curvature and $M_{1} / M_{2}<0$ for simple curvature. The coefficient $j$, shown in Equation 12, is obtained with Equations 14 to 17.

$$
j=\frac{1}{2 I_{y}}\left(\beta_{w}+\beta_{f}+\beta_{l}\right)+x_{0}
$$

$$
\beta_{w}=-\left(\frac{t x_{m} a_{m}^{3}}{12}+t x_{m}^{3} a_{m}\right)
$$


$\beta_{f}=\frac{t}{2}\left[\left(b_{m}-x_{m}\right)^{4}-x_{m}^{4}\right]+\frac{t a_{m}^{2}}{4}\left[\left(b_{m}-x_{m}\right)^{2}-x_{m}^{2}\right]$

$\beta_{l}=2 c_{m} t\left(b_{m}-x_{m}\right)^{3}+\frac{2}{3} t\left(b_{m}-x_{m}\right)\left[\left(\frac{a_{m}}{2}\right)^{3}-\left(\frac{a_{m}}{2}-c_{m}\right)^{3}\right]$

where $a_{m}$ is web width; $b_{m}$ is the flange width; $c_{m}$ is the lip width; $t$ is profile thickness; $x_{m}$ is the distance from shear center to web mid-thickness; and $x_{0}$ is the distance from the shear center to the centroid.

The compression buckling loads needed in Equation 12 are evaluated in agreement with Equations 18 and 19, where $I_{x}$ is the major axis moment of inertia (Figure 2b); $L$ is member length; $G_{s}$ is the transverse modulus of elasticity $(77 \mathrm{GPa}) ; J$ is the constant of torsion; $C_{w}$ is the warping constant; and $r_{0}$ is the polar radius of gyration of the gross cross section.

$N_{e x}=\frac{\pi^{2} E_{s} I_{x}}{L^{2}}$

$N_{e z}=\frac{1}{r_{0}^{2}}\left(\frac{\pi^{2} E_{s} C_{w}}{L^{2}}+G_{s} J\right)$

Finally, to calculate the elastic critical moments associated with distortional and local buckling of the steel profile cross section, the authors performed a Finite Strip Analysis via CUFSM [38]. When the lips are under compression due to the action of sagging bending moment, the elastic critical moments are $M_{l 1}=118.55 \mathrm{kN} . \mathrm{cm}$ and $M_{\text {dist }}=60.45 \mathrm{kN} \cdot \mathrm{cm}$, for local and distortional buckling, respectively (Figure 5); and when the web is under compression due to the action of hogging bending moment, the elastic critical moment of local buckling is $M_{l 2}=9.18 \mathrm{kN} \cdot \mathrm{cm}$ (Figure 6).

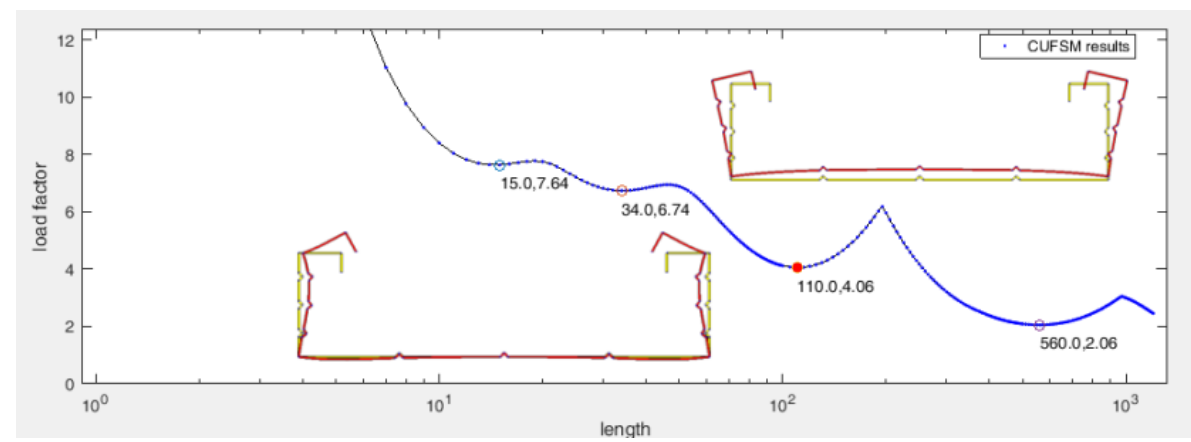

Figure 5. Finite-strip analysis result for sagging bending moment [38].

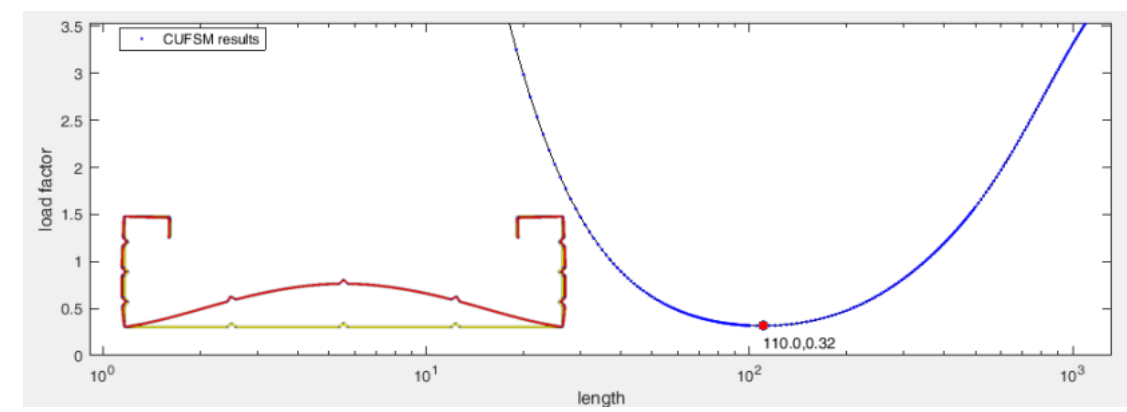

Figure 6. Finite-strip analysis result for hogging bending moment [38]. 


\subsubsection{Web crippling}

Under the action of concentrated loads such as external forces or reactions, cold-formed steel elements can fail due to compression of non-stiffened webs. The maximum design force for each flat portion of the web $\left(F_{w c, R d}\right)$ must be compared to the largest applied force in the ultimate limit state, according to Equation 20 [7].

$$
F_{w c, R d}=\frac{\alpha t_{w}^{2} f_{y} \operatorname{sen} \varphi}{1,35}\left(1-\alpha_{r} \sqrt{\frac{r_{i}}{t_{w}}}\right)\left(1+\alpha_{c} \sqrt{\frac{c}{t_{w}}}\right)\left(1-\alpha_{h} \sqrt{\frac{h_{w}}{t_{w}}}\right)
$$

where $\alpha$ is a parameter that depends on flange condition and load case; $t_{w}$ is the web thickness; $f_{y}$ is the design yield strength; $\varphi$ is the angle between the plane of the web and bearing surface, taken as $90^{\circ} ; \alpha_{r}, \alpha_{c}$ and $\alpha_{h}$ are coefficients that depend on the internal bending radius, bearing length and web slenderness, respectively; $r_{i}$ is the internal bending radius; $c$ is the bearing length; and $h_{w}$ is the flat dimension of web measured in its plane.

\subsubsection{Displacement control}

During construction, the CFS shuttering must have enough stiffness to grant structural safety and ensure shape and dimension of the molded concrete element [39]. Hence, it's important to control the deflections in the serviceability limit-state under the action of a uniformly distributed service load accounting for ponding. Since the shuttering is designed as a continuous beam, the Direct Stiffness Method was used to carry out the structural analysis and to calculate the displacements. The maximum deflection $\left(f_{\max }\right)$ of the beam must respect the limits of ABNT NBR 8800 [8], according to Equation 21, where $L$ is the span measured between props.

$$
f_{\max } \leq\left\{\begin{array}{c}
2 \mathrm{~cm} \\
L / 180
\end{array}\right.
$$

Nevertheless, if $f_{\max }$ exceeds $L / 250$, regardless of the limits stipulated in Equation 21, the service load must be incremented by $70 \%$ of the weight of a fictitious concrete layer with thickness $f_{\max }$. Then, a new displacement must be calculated and it must respect Equation 21.

\subsection{Design after concrete curing}

The design procedure for T-shaped concrete beams was previously detailed by Favarato et al. [33]. Here, only the key equations will be presented.

\subsubsection{Bending moment}

According to Figure 7a, the equilibrium of horizontal forces is given by $R+C+T=0$, where $R$ is net compression on concrete, $C$ is the force on the upper bar of the lattice girder (tension or compression, depending on neutral axis depth) and $T$ is net tension on the lattice girder's lower bars and additional rebar, taking compression as negative and tension as positive.

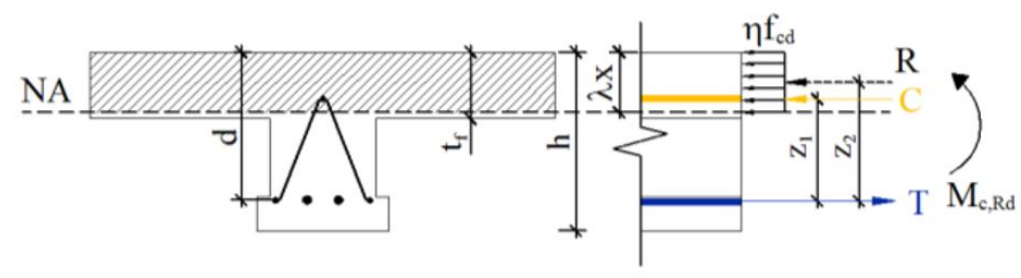

(a)

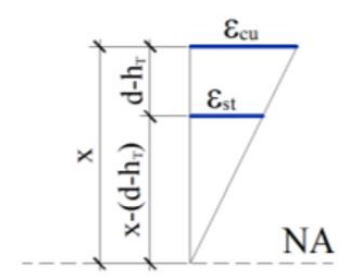

(b)

Figure 7. T-shaped beam under bending (extracted from Favarato et al. [33]). 
The depth of the Neutral axis (NA) is defined according to Equation 22:

$-\eta f_{c d} b_{f} \lambda x+E_{s a} \varepsilon_{s t} A_{s, c t}+f_{y d}\left(A_{s, t t}+A_{s, t a}\right)=0$

$\lambda x \leq t_{f}$

If Equation 23 is not satisfied, then Equation 24 shall be used, being Equation 25 now satisfied.

$-\eta f_{c d}\left(b_{f}-b_{w l}\right) h_{f}-\eta f_{c d} b_{w 1} \lambda x+E_{s a} \varepsilon_{s t} A_{s, c t}+f_{y d}\left(A_{s, t t}+A_{s, t a}\right)=0$

$\lambda x>t_{f}$

where $b_{f}$ is the flange width; $b_{w l}$ is the web thickness; $h_{f}$ is the flange thickness; $E_{s a}$ is the Young's Modulus of the steel lattice bars and rebar $(210 \mathrm{GPa}) ; A_{s, c t}$ is the cross-sectional area of the upper lattice girder bar; $f_{c d}$ is the design compressive strength of concrete; $f_{y d}$ is the design yield strength of reinforcement steel; $A_{s, t t}$ is the total cross-sectional area of lower bars of the truss; and $A_{s, t a}$ is the total area of additional rebar. The parameter $\varepsilon_{s t}$ is the strain of the upper bar of the lattice girder, calculated according to Equation 26, derived from Figure $7 \mathrm{~b}$.

$\varepsilon_{s t}=\varepsilon_{C U}-\frac{\varepsilon_{C U}\left(d-h_{T}\right)}{x}$

where $\varepsilon_{c u}$ is the strain of the concrete T-shaped section $(0.35 \%) ; d$ is defined in Figure $7 \mathrm{a} ; h_{T}$ is the lattice girder height; and $x$ is the neutral axis depth. Finally, the design bending moment shall be calculated as $M_{c, R d}=C z_{1}+R z_{2}$ [33], where the distances $z_{1}$ and $z_{2}$ can be determined with trigonometry.

\subsubsection{Shear force}

The design shear force on concrete beams with lattice girder reinforcements are determined by Equation 27, considering the ultimate limit-states of concrete crushing and diagonal tension [9].

$V_{c, R d} \leq\left\{\begin{array}{c}0.54\left(1-\frac{f_{c k}}{250}\right) f_{c d} b_{w l} d \sin ^{2} \theta(\operatorname{cotg} \alpha+\operatorname{cotg} \theta) \\ 0.6 f_{c t d} b_{w l} d+1.8 \frac{A_{s w}}{s} d(\operatorname{cotg} \alpha+\operatorname{cotg} \theta) \sin \alpha \sin \beta f_{y d}\end{array}\right.$

where $\theta$ is the inclination of concrete rods; $\alpha$ is inclination of transversal reinforcements (Figure 8); $\beta$ is inclination of transversal reinforcements in its plane (Figure 8); $d$ is the distance from the center of gravity of tensioned reinforcements to the top of the concrete surface; $f_{c t d}$ is the design tensile strength of concrete; $f_{c k}$ is the nominal compressive strength of concrete; $A_{s w}$ is the total area of transversal reinforcements; $s$ is the distance between successive transversal reinforcements; and $f_{y d}$ is the design yield strength of steel, as stated by Favarato et al. [33]. It's important to state that Equation 27 was adapted from ABNT NBR 6118 [9] - section 17.4.2, where the factor $\sin \alpha \sin \beta$ in the second line includes the effects of shear reinforcements slope in its plane. 

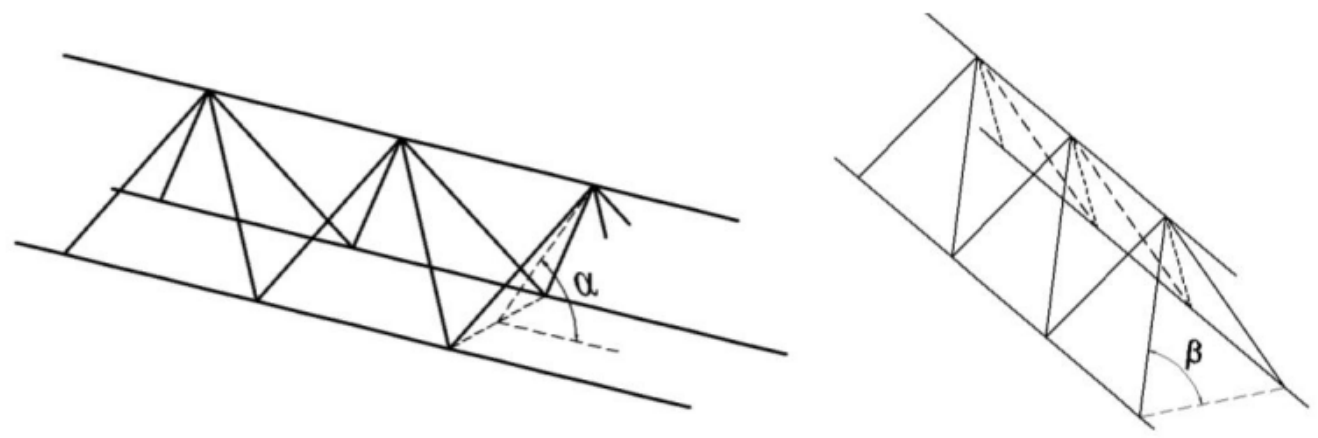

Figure 8. Slop of shear reinforcements (source: authors).

\subsubsection{Deflection}

In accordance with ABNT NBR 6118 [9], the maximum displacement are evaluated considering the effects of creep, limited to $L / 350$, where $L$ is the unpropped span. Furthermore, the reduction in the moment of inertia of the T-shaped concrete section due to cracking must be accounted for in the final deflection $\left(f_{t}\right)$, calculated with Equation 28.

$f_{t}=\frac{5 q_{q p} L^{4}}{384 E_{c s} I_{e}}\left(1+\alpha_{f}\right) \leq \frac{L}{350}$

where $q_{q p}$ is the uniformly distributed load for quasi-permanent combination; $E_{c s}$ is the secant Modulus of Elasticity of the concrete; $I_{e}$ is the reduced moment of inertia of the T-shaped concrete beam, considering the effects of cracking in the concrete's tensioned zone [9]; and $\alpha_{f}$ accounts for the effects of creep.

\subsubsection{Crach width}

This verification must use frequent load combinations [9] to assess the tensile stress in the steel bars in stage II. As stated before, the maximum crack width $\left(w_{k}\right)$ shall be restricted to $w_{k, \max }=0.30 \mathrm{~mm}$ in the serviceability limit-state. Crack width size is evaluated according to Equation 29.

$w_{k} \leq\left\{\begin{array}{c}\frac{\phi}{12.5 \eta_{1}} \frac{\sigma_{s}}{E_{s}} \frac{3 \sigma_{s}}{f_{c t m}} \\ \frac{\phi}{12.5 \eta_{1}} \frac{\sigma_{s}}{E_{s a}}\left(\frac{4}{\rho_{r}}+45\right)\end{array}\right.$

where $\phi$ is the largest diameter of rebar; $\eta_{1}$ is the adhesion coefficient; $E_{s a}$ is the Young's Modulus of the steel reinforcement; $f_{c t m}$ is the average concrete tensile strength; $\rho_{r}$ is the passive adherent reinforcement ratio; and $\sigma_{s}$ is stress on tensioned reinforcements on stage II, as detailed by Favarato et al. [33].

\subsection{Flow chart}

The proposed design procedure is summarized in Figure 9. The coefficients of utilization defined in the sequence are the relation between the parameter value, calculated with the program, and its maximum value regarding a limit-state, such as maximum bending moment and design bending moment, maximum deflection and limit deflection. 


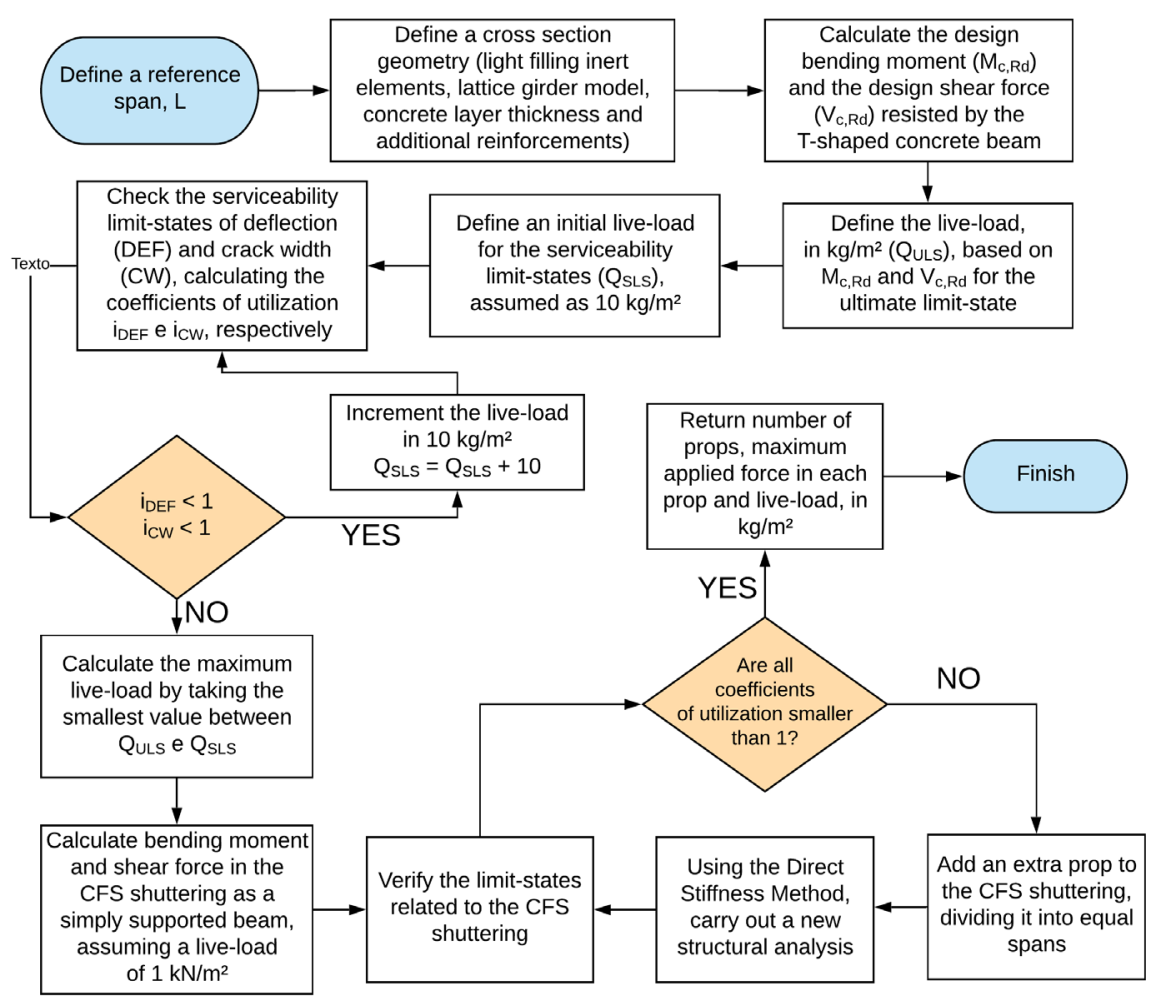

Figure 9. Design flow char (adapted from Favarato et al. [33]).

\section{RESULTS AND DISCUSSIONS}

To exemplify the design procedure for lattice girder slabs with CFS lipped channel section shuttering, the same geometries tested by Favarato et al. [33] were chosen for analysis, with the inclusion of propping (Table 1). The following material and cross-section geometric properties are considered: concrete compressive strength of $25 \mathrm{MPa}$; lattice girder model $8645\left(f_{y k}=600 \mathrm{MPa}\right)$, according to Figure 10; two additional reinforcement bars, $\varnothing 6.30 \mathrm{~mm}$ and $f_{y k}=500 \mathrm{MPa}$; specific weight of light filling material taken as $0.37 \mathrm{kN} / \mathrm{m}^{3}$; and a yield strength of cold-formed steel profile of $280 \mathrm{MPa}$. Two geometries were tested:

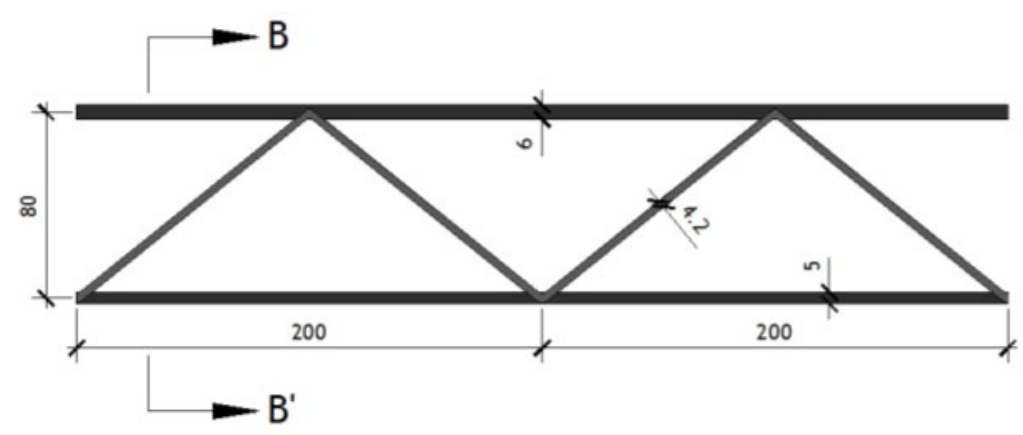

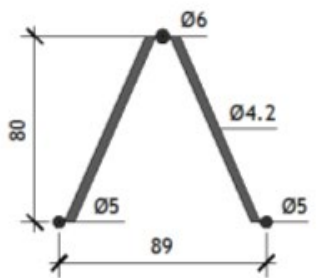

\section{Section BB'}

Figure 10. Lattice girder chosen for example, with dimensions in millimeters (source: authors).

a) Scenario 1:5 cm concrete layer thickness and $27 \times 8 \mathrm{~cm}$ light filling inert blocks.

b) Scenario 2: $6 \mathrm{~cm}$ concrete layer thickness and $37 \times 8 \mathrm{~cm}$ light filling inert blocks. 
The following convention has been used to indicate the limit-states in the graphs: BMac - bending moment after concrete curing; SFac - shear force after concrete curing; DEFac - deflection after concrete curing; CWac - crack width after concrete curing; BS+bc - combined sagging bending moment and shear force before concrete curing; BS$\mathrm{bc}$ - combined hogging bending moment and shear force before concrete curing; WCbc - web crippling before concrete curing; and DEFbc - deformation before concrete curing.

Table 1. Input data for analysis.

\begin{tabular}{|c|c|c|c|}
\hline Data type & Parameter & Value & Unit \\
\hline \multirow{7}{*}{ GENERAL DATA } & Shuttering yield strength & 280 & $\mathrm{MPa}$ \\
\hline & Concrete compressive strength & 25 & $\mathrm{MPa}$ \\
\hline & Lattice girder model & TR8645 & -- \\
\hline & Lattice girder yield strength & 600 & $\mathrm{MPa}$ \\
\hline & Additional rebar & $2 \varnothing 6.30$ & $\mathrm{~mm}$ \\
\hline & Additional rebar yield strength & 500 & $\mathrm{MPa}$ \\
\hline & Light filling material density & 0.37 & $\mathrm{kN} / \mathrm{m}^{3}$ \\
\hline \multirow{2}{*}{ SCENARIO 1} & Concrete layer thickness & 5 & $\mathrm{~cm}$ \\
\hline & Blocks dimensions & $27 \times 8$ & $\mathrm{~cm}$ \\
\hline \multirow{2}{*}{ SCENARIO 2} & Concrete layer thickness & 6 & $\mathrm{~cm}$ \\
\hline & Blocks dimensions & $37 \times 8$ & $\mathrm{~cm}$ \\
\hline
\end{tabular}

For scenario 1, according to Figure 11, the limit-state related to shear governs design for spans of up-to $1.60 \mathrm{~m}$, while bending moment is the critical limit-state for spans ranging from $1.60 \mathrm{~m}$ to $3.40 \mathrm{~m}$. For spans outside of these ranges, excessive deflection is the governing parameter. If the coefficient of utilization related to the governing limitstate for a given propped span exceeds 1.0, maximum prop spacing is equal to the length of that span. As such, the saw tooth graph presented in Figure 12 reports the number of props needed for each span: each time it reaches a peak, an extra prop must be included within the next span. Furthermore, local buckling of CFS profile elements in the region where props are introduced governed the design for all spans above $1.40 \mathrm{~m}$, which is attributed to the low buckling resistance to hogging bending moment. The coefficient of utilization related to the governing limit-state in Figure 12 does not need to reach 1.0 to stop the iterative process of analysis, since before concrete curing the steel element is only verified with regards to the aforementioned limit-states, considering a pre-defined live-load of $1 \mathrm{kN} / \mathrm{m}^{2}$.

For scenario 2, similar conclusions are drawn from Figure 13 and Figure 14. The shear resistance in the concrete section also governs the design for short spans, followed by bending moment and, finally, total deflection. However, it is important to state that the maximum unpropped span in this scenario is reduced from $1.2 \mathrm{~m}$ to $1.0 \mathrm{~m}$ when compared to the previous analysis. This arises from the low buckling resistance of the CFS profile and the heavier concrete deadload due to wider concrete section flanges.

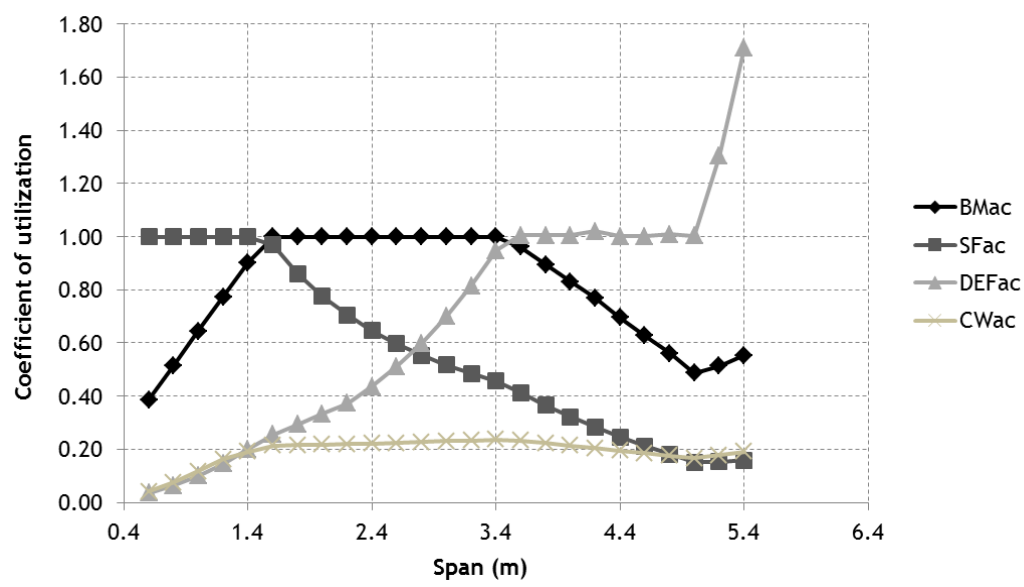

Figure 11. Scenario 1 analysis result - limit-states after concrete curing (source: authors). 


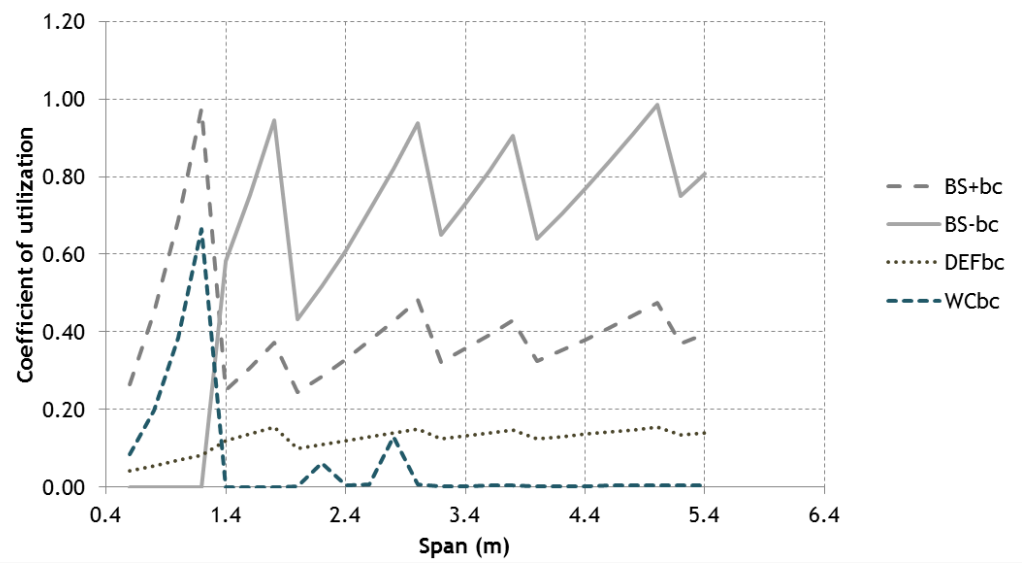

Figure 12. Scenario 1 analysis result - limit-states before concrete curing (source: authors).

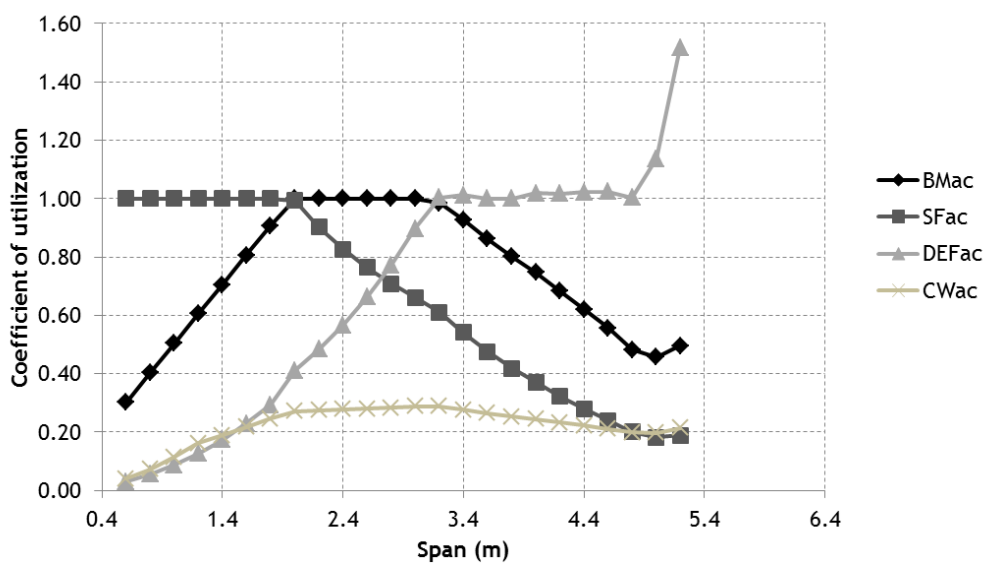

Figure 13. Scenario 2 analysis result - limit-states after concrete curing (source: authors).

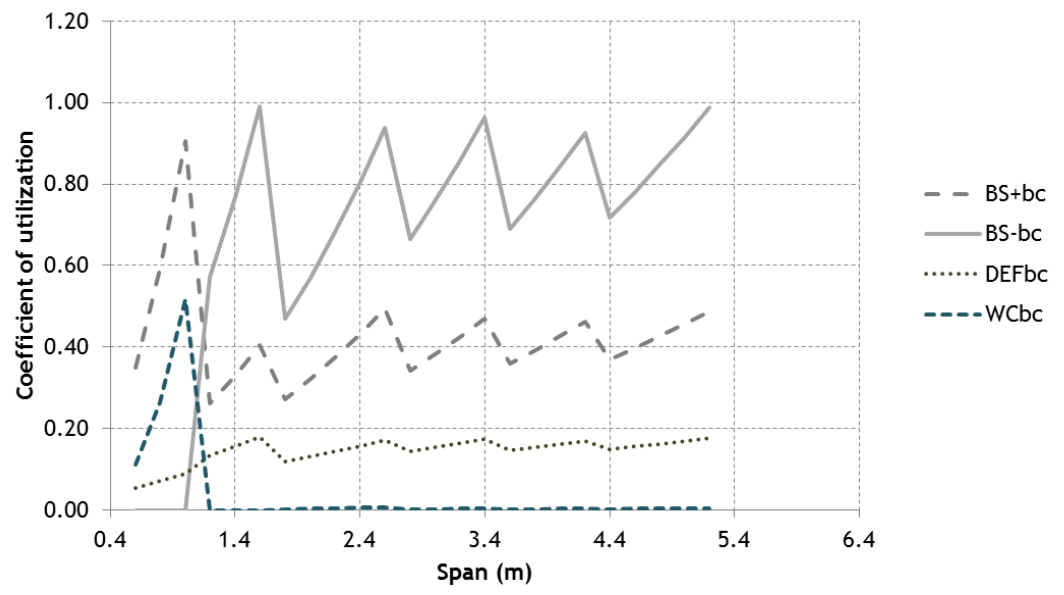

Figure 14. Scenario 2 analysis result - limit-states before concrete curing (source: authors).

The graph in Figure 15, compares the load capacity of scenarios 1 and 2 as a function of span. In scenario 1, heavier service loads can be applied to spans of up-to $1.80 \mathrm{~m}$ due to shear failure being the predominant limit-state. From $1.80 \mathrm{~m}$ to $3.40 \mathrm{~m}$, the maximum service load of scenario 2 becomes larger since bending moment governs the design. 
This is a result of the T-shaped concrete beams having larger flanges. After $3.40 \mathrm{~m}$, the deflection governs the design and any marginal increase of section height in scenario 2 does not compensate for the increase in weight. In general, scenario 1 shows a better performance when compared to its alternative.

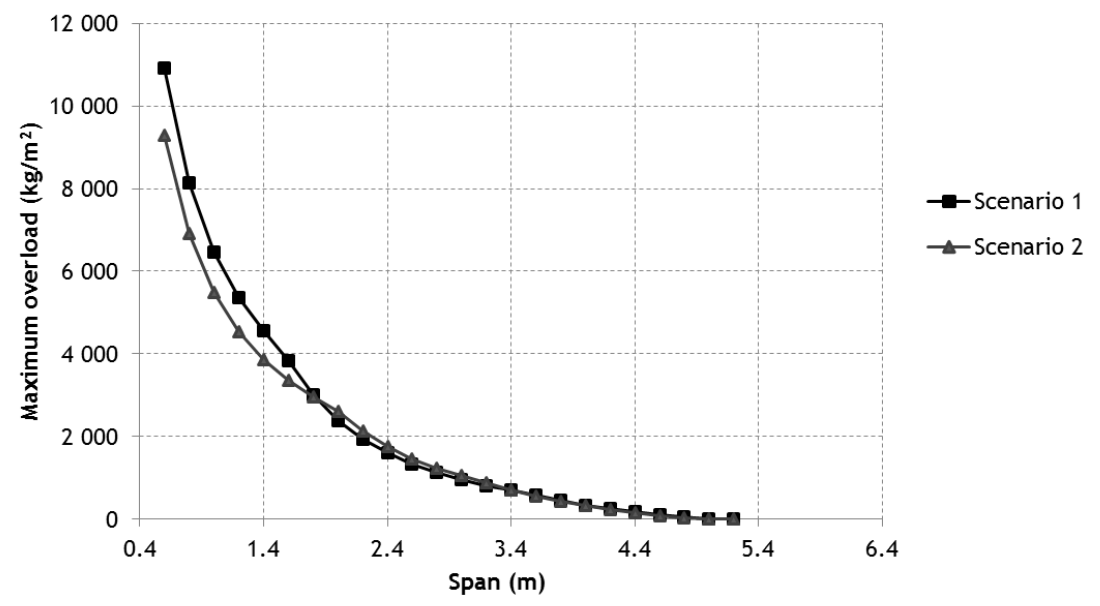

Figure 15. Service loads for both scenarios 1 and 2 (source: authors).

Lastly, the maximum allowable force on propping devices is assessed. This parameter is plotted against unpropped span (Figure 16) - the slab's span in service, highlighting the linear relationship between them. The saw tooth behavior is attributed to the gradual increase in the number of props added during construction, and each peak indicates the occurrence of a limit state of the steel shuttering. The graph shows that the average applied force is $1.50 \mathrm{kN}$ in each rib, for spans from $2.0 \mathrm{~m}$ up-to $5.2 \mathrm{~m}$.

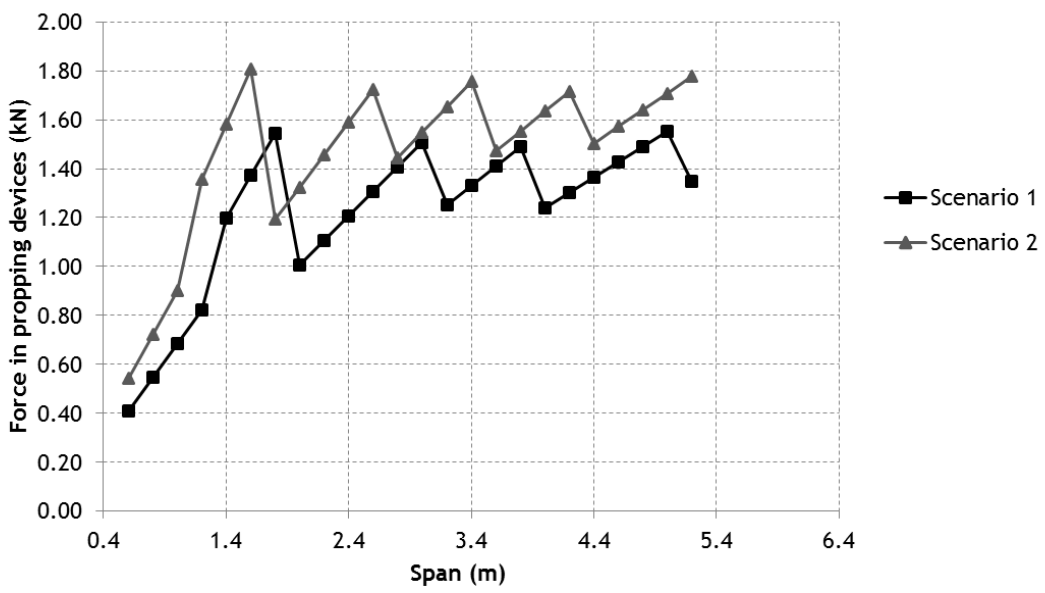

Figure 16. Maximum force applied in the propping devices during construction phase (source: authors).

In summary, the computational tool presented can be used to propose design guidelines for this new slab system, regardless of changes in configuration (lattice girder model, concrete strength, light filling material specification, steel yield strength, additional reinforcements, unpropped span). Since there are no specifications and no previous research for this exact slab system, the results obtained herein are conservative and can be taken as an estimation of design parameters that ensure minimum structural safety. On another note, the large number of props needed before concrete curing is a result of the low stiffness of each cold-formed steel rib, which is a critical factor for unpropped construction. 


\section{SUMMARY AND CONCLUSIONS}

This research is inspired by a recently released solution in the civil construction market for composite slabs. In this paper, a practical design procedure is proposed to evaluate the load capacity of lattice girder slabs with CFS lipped channel sections, bent about the minor axis of inertia. In general, the following conclusions can be drawn:

- The combination of different design standards gave rise to a simplified procedure to determine the maximum service load of Trelifácil ${ }^{\circledR}$ slabs. The amount of propping needed in the construction phase and the maximum forces applied in propping devices are also determined. Since no data is available from experimental tests to asses shear transfer due to the action of embossments, the composite action was neglected. Thus, the service load is conservatively estimated.

- Different limit-states control the system's behavior. The resistance of short spans $(L \leq 1.40 \mathrm{~m})$ is governed by shear force, while medium $(1.40<L \leq 3.40 \mathrm{~m})$ and long $(L>3.40 \mathrm{~m})$ spans are governed by bending moment and maximum displacements, respectively, in the serviceability phase.

- The reduced spacing between props in the construction phase and the maximum length of unpropped spans are a consequence of the CFS profile presenting low stiffness, in turn due to its thickness and cross-sectional dimensions. However, the coupling between the CFS profile and the lattice girder - neglected here on the absence of experimental results - can potentially allow for longer unpropped spans. This combined action could reduce compression on the lower flange. As such, resistance to local buckling of flanges, the ultimate limit-state that governs almost all propped design, would increase.

- The results suggest a strong limitation of unpropped construction due to the low performance of the cold-formed profile under minor axis bending. On the other hand, the coupled behavior and the actual composite action would certainly lead to less conservative results.

\section{ACKNOWLEDGEMENTS}

The authors acknowledge ArcelorMittal Tubarão, Federal University of Espirito Santo, CAPES, CNPq and FAPES for the financial support during this research.

\section{REFERENCES}

[1] A. P. A. Sieg, "Estudo de um sistema de laje com forma de aço incorporada," M.S. thesis, Esc. Eng., Univ. São Paulo, São Carlos, 2015.

[2] M. Crisinel and D. O'Leary, "Recent developments in steel/concrete composite slabs," Struct. Eng. Int., vol. 6, pp. 41-46, 1996, http://dx.doi.org/10.2749/101686696780495923.

[3] C. E. Javaroni, "Perfis de aço formados a frio: análise teórico-experimental”, Ph.D. dissertation, Esc. Eng., Univ. São Paulo, São Carlos, 1999.

[4] G. Queiroz, R. J. Pimenta, and A. G. Martins, Estruturas Mistas - vol. 1, 2nd ed. Rio de Janeiro: Instituto Aço Brasil, Centro Brasileiro da Construção em Aço, 2012.

[5] ArcelorMittal, Trelifácil ${ }^{\circledR}$ - Informative folder, 2017.

[6] Associação Brasileira de Normas Técnicas, Lajes Pré-fabricadas de Concreto - Parte 2 - Elementos Inertes para Enchimento e Fôrma-Requisitos, NBR 14859-2, 2016.

[7] Associação Brasileira de Normas Técnicas, Dimensionamento de Estruturas de Aço Constituidas por Perfis Formados a Frio, NBR 14762, 2010.

[8] Associação Brasileira de Normas Técnicas, Projeto de Estruturas de Aço e de Estruturas Mistas de Aço e Concreto de Edificios, NBR 8800, 2008.

[9] Associação Brasileira de Normas Técnicas, Projeto de Estruturas de Concreto - Procedimento, NBR 6118, 2014.

[10] I. M. Ahmed and K. D. Tsavdaridis, "The evolution of composite flooring systems: applications, testing, modelling and Eurocode design approaches," J. Construct. Steel Res., vol. 155, pp. 286-300, Apr 2019, http://dx.doi.org/10.1016/j.jcsr.2019.01.007.

[11] S. A. L. Andrade, P. C. G. S. Vellasco, J. G. S. Silva, and T. H. Takey, "Standardized composite slab systems for building constructions," J. Construct. Steel Res., vol. 60, no. 3-5, pp. 493-524, Mar-May 2004, http://dx.doi.org/10.1016/S0143974X(03)00126-3.

[12] J. C. Vianna, S. A. L. Andrade, P. C. G. S. Vellasco, L. R. O. Lima, and J. G. S. Silva, "Um sistema de laje mista para edificações residenciais usando perfis de chapa dobrada com corrugações," REM Rev. Escola Minas, vol. 60, no. 2, pp. 325-331, Apr-Jun 2007, http://dx.doi.org/10.1590/S0370-44672007000200015. 
[13] Y. J. Jeong, "Simplified model to predict partial-interactive structural performance of steel-concrete composite slabs," J. Construct. Steel Res., vol. 64, no. 2, pp. 238-246, Feb 2008, http://dx.doi.org/10.1016/j.jcsr.2007.05.003.

[14] J. C. Vianna, L. F. Costa-Neves, P. C. G. S. Vellasco, and S. A. L. Andrade, "Structural behaviour of T-Perfobond shear connectors in composite girders: An experimental approach," Eng. Struct., vol. 30, no. 9, pp. 2381-2391, Sep 2008, http://dx.doi.org/10.1016/j.engstruct.2008.01.015.

[15] J. C. Vianna, L. F. Costa-Neves, P. C. G. S. Vellasco, and S. A. L. Andrade, "Experimental assessment of Perfobond and TPerfobond shear connectors' structural response," J. Construct. Steel Res., vol. 65, no. 2, pp. 408-421, Feb 2009, http://dx.doi.org/10.1016/j.jcsr.2008.02.011.

[16] J. Holomek and M. Bajer, "Experimental and numerical investigation of composite action of steel concrete slab," Eng. Procedia, vol. 40, pp. 143-147, 2012, http://dx.doi.org/10.1016/j.proeng.2012.07.070.

[17] C. T. T. Hsu, S. Punurai, W. Punurai, and Y. Majdi, "New composite beams having cold-formed steel joists and concrete slab," Eng. Struct., vol. 71, pp. 187-200, Jul 2014, http://dx.doi.org/10.1016/j.engstruct.2014.04.011.

[18] K. K. Alenezi et al., "Behavior of pre-cast U-shaped composite beam integrating cold-formed steel with ferro-cement slab," Thinwalled Struct., vol. 102, pp. 18-29, May 2016, http://dx.doi.org/10.1016/j.tws.2016.01.014.

[19] K. M. A. Hossain, S. Alam, M. S. Anwar, and K. M. Y. Julkarnine, "High performance composite slabs with profiled steel deck and engineered cementitious composite - strength and shear bond characteristics," Constr. Build. Mater., vol. 125, pp. 227-240, Oct 2016., http://dx.doi.org/10.1016/j.conbuildmat.2016.08.021.

[20] M. Lasheen, A. Shaat, and A. Khalil, "Behaviour of lightweight concrete slabs acting compositely with steel I-sections," Constr. Build. Mater., vol. 124, pp. 967-981, Oct 2016, http://dx.doi.org/10.1016/j.conbuildmat.2016.08.007.

[21] D. Waldmann, A. May, and V. B. Thapa, "Influence of the sheet profile design on the composite action of slabs made of lightweight woodchip concrete," Constr. Build. Mater., vol. 148, pp. 887-899, Sep 2017, http://dx.doi.org/10.1016/j.conbuildmat.2017.04.193.

[22] Y. Majdi, C. T. T. Hsu, and M. Zarei, "Finite element analysis of new composite floors having cold-formed steel and concrete slab," Eng. Struct., vol. 77, pp. 65-83, Oct 2014, http://dx.doi.org/10.1016/j.engstruct.2014.07.030.

[23] M. M. Florides and K. A. Cashell, "Numerical modelling of composite floor slabs subject to large deflections," Structures, vol. 9, pp. 112-122, Feb 2017, http://dx.doi.org/10.1016/j.istruc.2016.10.003.

[24] J. Suizi, C. Wanlin, Z. Yuchen, and Y. Quan, "Simplified calculation model and finite-element analysis of frame-supported ribbedgrid composite slab structure," KSCE J. Civ. Eng., vol. 22, no. 9, pp. 3383-3394, Jan 2018, http://dx.doi.org/10.1007/s12205-0170457-5.

[25] K. M. A. Hossain, S. Attarde, and M. S. Anwar, "Finite element modelling of profiled steel deck composite slab system with engineered cementitious composite under monotonic loading," Eng. Struct., vol. 186, pp. 13-25, May 2019, http://dx.doi.org/10.1016/j.engstruct.2019.02.008.

[26] X. Zhou, Y. Shi, L. Xu, X. Yao, and W. Wang, "A simplified method to evaluate the flexural capacity of lightweight cold-formed steel floor system with oriented strand board subfloor," Thin-walled Struct., vol. 134, pp. 40-51, Jan 2019, http://dx.doi.org/10.1016/j.tws.2018.09.006.

[27] P. Kyvelou, L. Gardner, and D. A. Nethercot, "Design of composite cold-formed steel flooring systems," Structures, vol. 12, pp. 242252, Nov 2017, http://dx.doi.org/10.1016/j.istruc.2017.09.006.

[28] E. Y. L. Chien and J. K. Ritchie, "Composite floor systems - a mature design option," J. Construct. Steel Res., vol. 25, no. 1-2, pp. 107-139, 1993, http://dx.doi.org/10.1016/0143-974X(93)90055-W.

[29] R. P. Johnson and A. J. Shepherd, "Resistance to longitudinal shear of composite slabs with longitudinal reinforcement," $J$. Construct. Steel Res., vol. 82, pp. 190-194, Mar 2013, http://dx.doi.org/10.1016/j.jcsr.2012.12.005.

[30] T. Limazie and S. Chen, "Numerical procedure for nonlinear behavior analysis of composite slim floor beams," J. Construct. Steel Res., vol. 106, pp. 209-219, Mar 2015, http://dx.doi.org/10.1016/j.jcsr.2014.12.015.

[31] G. Ranzi and A. Ostinelli, "Ultimate behaviour and design of post-tensioned composite slabs," Eng. Struct., vol. 150, pp. 711-718, Nov 2017, http://dx.doi.org/10.1016/j.engstruct.2017.07.075.

[32] G. Q. Li, J. Z. Zhang, and J. Jiang, "Analytical modeling on collapse resistance of steel beam-concrete slab composite substructures subjected to side column loss," Eng. Struct., vol. 169, pp. 238-255, Aug 2018, http://dx.doi.org/10.1016/j.engstruct.2018.05.038.

[33] L. F. Favarato, A. F. G. Calenzani, J. C. V. Pires, E. Junges, and J. A. Ferrareto, "Evaluation of the resistance of trussed slabs with steel formwork in cold formed U profile," Lat. Am. J. Solids Struct., vol. 16, no. 7, pp. 1-18, Aug 2019, http://dx.doi.org/10.1590/1679-78255304.

[34] D. C. M. Candido, A. P. Storch, A. V. S. Gomes, L. F. Favarato, and A. F. G. Calenzani, "Análise numérica de flambagem de perfis de aço formados a frio empregados em lajes nervuradas mistas," in An. XIII Simp. Mec. Comp., Vitória, ES, Brasil, Oct. 2018.

[35] W. W. Yu and R. A. Laboube, Cold-formed Steel Design, 4th ed. Hoboken: John Wiley e Sons, 2010.

[36] American Iron And Steel Institute, North American Specification for the Design of Cold-Formed Steel Structural Members, S100-16, 2016. 
[37] Standards Association of Australia. Standards New Zealand, Cold-formed Steel Structures, AS/NZS 4600, 2005.

[38] B. Schafer, WCUFSM 5.01 - Finite Strip Elastic Buckling Analysis Application. Baltimore, USA: Johns Hopkins University, 2018. [Online]. Available: https://www.ce.jhu.edu/cufsm/downloads/

[39] Associação Brasileira de Normas Técnicas, Fôrmas e Escoramentos para Estruturas de Concreto - Projeto, Dimensionamento e Procedimentos Executivos, NBR 15696, 2009.

Author contributions: Conceptualization: L. F. Favarato, A. V. S. Gomes, D. C. M. Candido, A. F. G. Calenzani, J. C. Vianna, J. A. Ferrareto / Methods: L. F. Favarato / Analysis: L. F. Favarato / Writing - original draft: L. F. Favarato / Writing - review and editing: L. F. Favarato, A. V. S.

Gomes, D. C. M. Candido, A. F. G. Calenzani, J. C. Vianna, J. A. Ferrareto / Resources: J. A. Ferrareto / Supervision: J. C. Vianna, J. A. Ferrareto, A. F. G. Calenzani.

Editors: Vladimir Guilherme Haach, José Luiz Antunes de Oliveira e Sousa, Guilherme Aris Parsekian. 